\title{
WIP1 phosphatase as pharmacological target in cancer therapy
}

\author{
Soňa Pecháčková ${ }^{1} \cdot$ Kamila Burdová $^{1} \cdot \operatorname{Libor}^{\text {Macurek }^{1}}{ }^{1}$
}

Received: 3 March 2017 /Revised: 13 April 2017 / Accepted: 19 April 2017 /Published online: 24 April 2017

(C) The Author(s) 2017. This article is an open access publication

\begin{abstract}
DNA damage response (DDR) pathway protects cells from genome instability and prevents cancer development. Tumor suppressor p53 is a key molecule that interconnects DDR, cell cycle checkpoints, and cell fate decisions in the presence of genotoxic stress. Inactivating mutations in TP53 and other genes implicated in DDR potentiate cancer development and also influence the sensitivity of cancer cells to treatment. Protein phosphatase $2 \mathrm{C}$ delta (referred to as WIP1) is a negative regulator of DDR and has been proposed as potential pharmaceutical target. Until recently, exploitation of WIP1 inhibition for suppression of cancer cell growth was compromised by the lack of selective small-molecule inhibitors effective at cellular and organismal levels. Here, we review recent advances in development of WIP1 inhibitors and discuss their potential use in cancer treatment.
\end{abstract}

Keywords Cancer $\cdot$ Phosphatase $\cdot$ Checkpoint $\cdot$ DNA damage response $\cdot$ Inhibitor $\cdot$ p53

\section{Introduction}

Genetic information is continuously endangered by erroneous DNA metabolism as well as by various environmental factors that include ionizing radiation or chemotherapy representing two major non-surgical approaches in cancer therapy. Cells respond

Libor Macurek

macurek@img.cas.cz

1 Department of Cancer Cell Biology, Institute of Molecular Genetics of the ASCR, CZ-14220 Prague, Czech Republic to genotoxic stress by activation of a conserved DNA damage response pathway (DDR) that abrogates cell cycle progression and facilitates DNA repair. This safeguard mechanism represents an intrinsic barrier preventing genome instability and protecting cells against tumor development [1-4]. Depending on the mode and level of DNA damage, DDR signaling network promotes temporary cell cycle arrest (checkpoint), permanent growth arrest (senescence), or programmed cell death (apoptosis). Genes coding for proteins involved in DDR are typically tumor suppressors and are commonly mutated in cancer. The DDR pathway is regulated by a spatiotemporally controlled cascade of posttranslational modifications of key proteins including protein phosphorylation and ubiquitination [5]. Following DNA damage, upstream protein kinases ATM and ATR are activated and spread the signal through phosphorylation of downstream transducing kinases CHK2 and CHK1 to rapidly establish the checkpoint arrest. Subsequently, checkpoint is reinforced by activation of the tumor suppressor protein p53 and its transcriptional target p21 that inactivates cyclin-dependent kinases.

After completion of DNA repair, activity of the DDR pathway is terminated by protein phosphatases that allow checkpoint recovery and restart cell proliferation. Serine/threonine phosphatases of PP2C family are evolutionary conserved negative regulators of cell stress response pathways and function as monomeric enzymes comprising of a conserved $\mathrm{N}$-terminal phosphatase domain and non-catalytic C-terminal part [6]. Protein phosphatase $2 \mathrm{C}$ isoform delta is ubiquitously expressed at basal levels and its expression is strongly induced after exposure of cells to genotoxic stress in a p53-dependent manner (hence its alternative name WIP1 for wild-type p53-induced protein 1) [7]. Substrate specificity of the chromatin-bound WIP1 matches the phosphorylation sites imposed by ATM kinase, and thus, WIP1 can efficiently dephosphorylate $\mathrm{p} 53, \gamma \mathrm{H} 2 \mathrm{AX}$, and possibly also other proteins involved in DDR $[8,9]$. Downregulation of WIP1 by RNA interference leads to prolongation of the G2 checkpoint 
whereas overexpression of WIP1 causes checkpoint override $[10,11]$. WIP1 phosphatase is overexpressed in multiple human cancers and was reported to act as oncogene. Conversely, loss of WIP1 delayed the onset of tumor development in mouse models [12-14]. Similarly, RNAi-mediated depletion of WIP1 inhibited cancer cell growth implicating WIP1 as promising pharmacological target [14]. Here, we discuss recent advances in development of a selective WIP1 inhibitor with proven efficiency in animal models and its potential use in cancer therapy.

\section{DNA damage response and role of WIP1 in checkpoint recovery}

Various kinds of genotoxic stress activate kinases of PI3kinase like family, including activation of ATM by DNA double-strand breaks (DSBs) and ATR by exposed singlestranded DNA (ssDNA) at stalled replication forks or resected DSBs (Fig. 1). ATM and ATR phosphorylate the effector checkpoint kinases $\mathrm{CHK} 2$ and $\mathrm{CHK} 1$ that target phosphatases $\mathrm{Cdc} 25 \mathrm{~A} / \mathrm{B} / \mathrm{C}$ leading to inactivation of cyclin-dependent kinases (CDKs) and cell cycle arrest. Under basal conditions, p53 is degraded by the E3 ubiquitin ligase MDM2 and transcriptionally inactivated at promoters by its enzymatically inactive homolog MDMX [15-18]. Following DNA damage, p53 is posttranslationally modified by ATM/CHK2, ATR/ CHK1, and various acetyltransferases leading to its stabilization and oligomerization, binding to promoters and triggering transcription of various target genes involved in cell cycle arrest, DNA repair, apoptosis, senescence, and metabolism $[19,20]$. CDKN1/p21 is a transcriptional target of p53 and potent inhibitor of CDKs that promotes maintenance of the G1 and $\mathrm{G} 2$ checkpoint. In non-stressed cells, expression of CDKN1/p21 is repressed by transcription intermediary factor 1-beta (also called KAP1) [21]. Phosphorylation of KAP1 at Ser824 by ATM and at Ser473 by CHK1/2 induced by genotoxic stress allows de-repression of CDKN1/p21 and contributes to checkpoint activation [21,22].

Besides arresting the cell cycle progression, ATM promotes DNA repair by phosphorylating histone variant $\mathrm{H} 2 \mathrm{AX}$ at $\mathrm{S} 139$ (called $\gamma \mathrm{H} 2 \mathrm{AX}$ ) in the flanking chromatin and plethora of other DNA repair proteins. $\gamma \mathrm{H} 2 \mathrm{AX}$ acts as a docking platform for various mediator proteins and ubiquitin ligases that jointly regulate recruitment of either 53BP1 or BRCA1 proteins to the close proximity of the DNA lesion and thus control the DNA repair pathway choice [23].

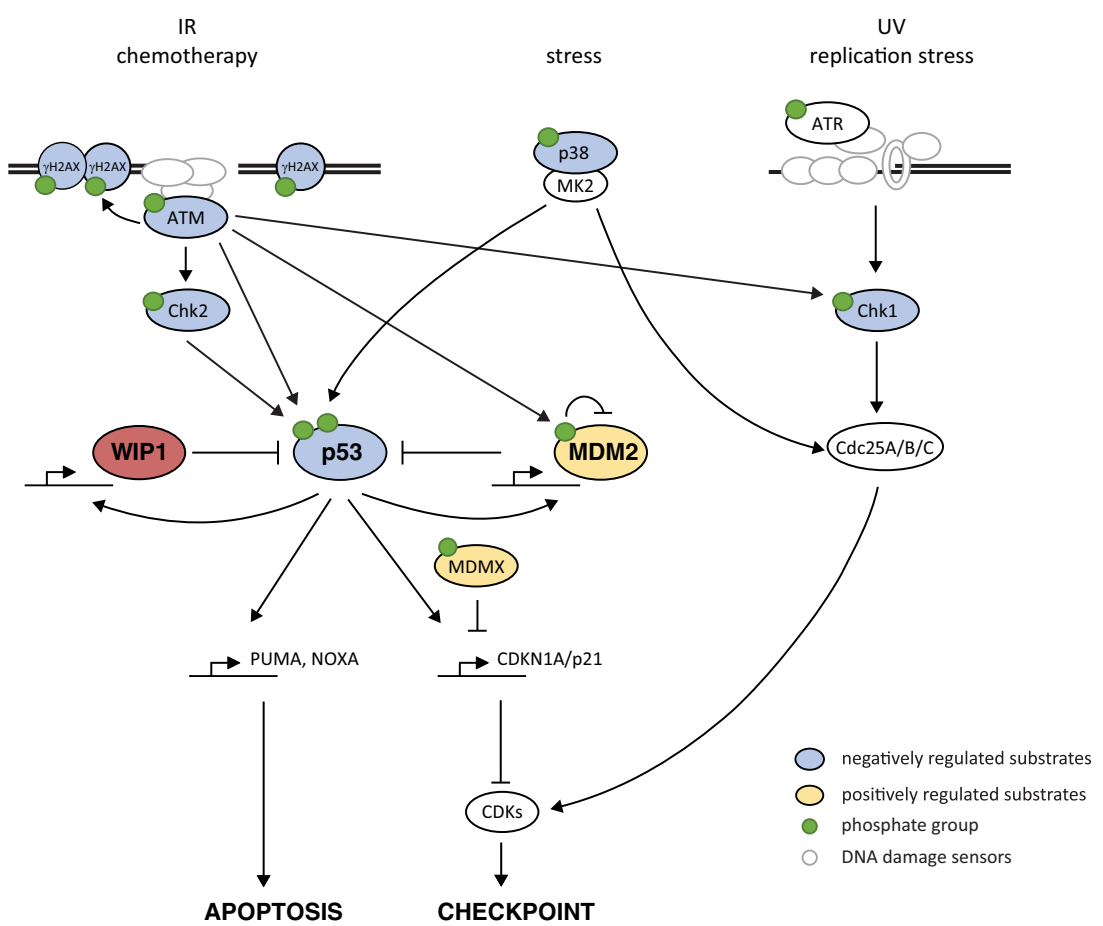

Fig. 1 Role of WIP1 phosphatase in termination of DNA damage response. Exposed ssDNA caused by stalled replication forks or resected DSBs activates ATR/CHK1 pathway that targets CDC25 family of phosphatases, prevents activation of CDKs, and triggers cell cycle arrest. DSBs induced by ionizing radiation or chemotherapy activate ATM that orchestrates DNA repair by phosphorylating histone $\mathrm{H} 2 \mathrm{AX}$ at chromatin and activates the cell cycle checkpoint. This is achieved by phosphorylation of $\mathrm{p} 53$ and $\mathrm{Mdm} 2$ that allows stabilization

of $\mathrm{p} 53$ and triggers expression of CDKN1/p21. In addition, p53 stimulates expression of its negative regulators Mdm2 and WIP1. After accumulating sufficient protein levels, WIP1 inactivates $\mathrm{p} 53$ pathway and dephosphorylates other targets jointly contributing to termination of the DDR (negatively and positively regulated WIP1 substrates shown in blue and yellow, respectively). Persistent genotoxic stress can continuously activate p53 leading to senescence. Very high activation of p53 pathway leads to expression of PUMA and NOXA and leads to cell death 
Whereas 53BP1 in complex with RIF1 blocks DSB resection and promotes non-homologous end joining, recruitment of BRCA1 stimulates resection and therefore facilitates homologous recombination (HR). After completion of DNA repair, cells recover from the checkpoint arrest and reenter the cell cycle. By targeting claspin, an important cofactor of ATR, PLK1 kinase terminates the activation of CHK1 and is essential for recovery from the G2 checkpoint [24]. In addition, various protein phosphatases directly reverse multiple phosphorylations imposed by ATM/ATR and CHK $1 / 2$ and thus contribute to timely inactivation of DDR [25]. In particular, protein phosphatase PP4 targets Ser 473 of KAP1 and has been implicated in recovery from the G1 checkpoint [26]. In contrast, WIP1 is needed for recovery from the G2 checkpoint $[11,26]$. Whereas expression of WIP1 is potentiated by $\mathrm{p} 53$, it acts as a strong negative regulator of $\mathrm{p} 53$ pathway thus forming a negative feedback loop that allows termination of p53 response after completion of DNA repair [11]. WIP1 inhibits p53 directly by dephosphorylating Ser 15 and indirectly through the stimulation of its negative regulators MDM2 and MDMX [10, 27-30]. In fact, WIP1 activity is needed throughout the G2 checkpoint to limit the level of p53/p21 pathway activation and to prevent degradation of cyclin $\mathrm{B}$ and a permanent cell cycle exit [31,32]. Similarly, WIP1 was shown to suppress DNA damage-induced apoptosis in different cell types [33-35]. Besides targeting p53 pathway, WIP1 contributes to termination of DDR by dephosphorylation of ATM at Ser1981 and $\gamma \mathrm{H} 2 \mathrm{AX}$ at chromatin [9, 36-38]. Other reported substrates of WIP1 include active forms of CHK1, CHK2, and p38 that reside mostly in nucleoplasm [10, 39, 40]. Although WIP1 can dephosphorylate these proteins in vitro or when overexpressed, the physiological role of the chromatinbound WIP1 in targeting these pathways remains unclear. Similarly, WIP1 was reported to counteract phosphorylation of the p65 subunit of NF-KB at Ser536 but more data are needed to clarify to what extent WIP1 regulates NF- $\mathrm{kB}$ pathway in inflammation [41].

Function of WIP1 is controlled in context of the cell cycle. Expression of WIP1 protein is low in G1, peaks in S/G2, and decreases during mitosis [42]. WIP1 is phosphorylated at multiple residues within the catalytic domain during mitosis which promotes its degradation by $\mathrm{APC} / \mathrm{cdc} 20$ in prometaphase [42]. Absence of WIP1 in mitosis may allow cells to recognize low levels of endogenous DNA damage present in condensed chromosomes. These sites are labeled by $\gamma \mathrm{H} 2 \mathrm{AX}$ during mitosis and they are repaired after mitotic exit in subsequent G1 phase. During interphase, WIP1 is constitutively phosphorylated at Ser54 and Ser85 by HIPK2 kinase that results in a rapid turnover of WIP1 [43]. Keeping basal levels of WIP1 low probably allows cells to fully activate DDR in the presence of genotoxic stress, whereas p53dependent induction of WIP1 expression allows termination of DDR after completion of DNA repair.

\section{WIP1 phosphatase as an oncogene}

About a half of human solid tumors exhibit somatic mutations in the TP53 gene that cause a deficient response to genotoxic stress and are commonly associated with poor prognosis $[44,45]$. On the other hand, tumors carrying wild-type TP53 frequently accumulate mutations in other genes that functionally compromise the p53 pathway and thus potentiate cell proliferation. As described above, WIP1 phosphatase is a negative regulator of DDR pathway and enhanced activity of WIP1 can contribute to tumor development.

WIP1 is encoded by PPM1D gene located at chromosomal locus 17q23.2 and its amplification was reported in about $10 \%$ of breast cancers [46, 47]. Importantly, amplification of $P P M 1 D$ occurred significantly more often in breast tumors that retained wild-type TP53 [46, 47] (Fig. 2). Similarly, common amplification of PPMID was found in ovarian clear cell carcinoma, where mutations in TP53 are relatively rare, but not in a more common serous carcinoma that typically contains mutated TP53 [50,51]. Besides breast and ovarian cancer, $P P M 1 D$ copy numbers gain or overexpression at mRNA level were reported also in glioma, neuroblastoma, and medulloblastoma [47, 51-58]. High expression of WIP1 was also observed by immunohistological methods in a fraction of lung adenocarcinomas and gastric and colorectal cancers $[55,59,60]$. However, caution should be taken when interpreting the histopathological data, since none of the currently available antibodies was sufficiently validated in histological assays and the staining pattern does not correspond with expected nuclear localization of WIP1. Besides amplification, nonsense mutations occur in a hotspot region of the exon 6 of PPM1D [61, 62]. These point mutations of PPMID result in expression of C-terminally truncated variants of WIP1 that exhibit higher protein stability and disable full activation of the checkpoint after genotoxic stress [62]. Besides breast and ovarian cancer, this type of mutations has been found in brainstem gliomas, lung adenocarcinoma, and prostate cancer [61-67]. WIP1 truncating mutations are considerably less common than PPM1D amplifications (usually below 1\%) and their occurrence was reported to further increase after chemotherapy [66]. Although gain-of-function mutations in PPMID efficiently suppress p53 function, their pathogenic role in cancer development still needs to be experimentally tested.

Amplification of $P P M 1 D$ was initially suggested to promote breast cancer development through inactivation of the p53 and p38 MAPK pathways [52,68]. In the same time, however, MMTV-driven overexpression of PPM1D in mice did not promote mammary tumor formation within 2 years suggesting that oncogenic properties of WIP1 may be relatively low $[52,69]$. About one third of breast tumors with $P P M 1 D$ overexpression showed also amplification of $E R B B 2$ suggesting that these two oncogenes may 
Breast Invasive Carcinoma dataset $(\mathrm{n}=817)$

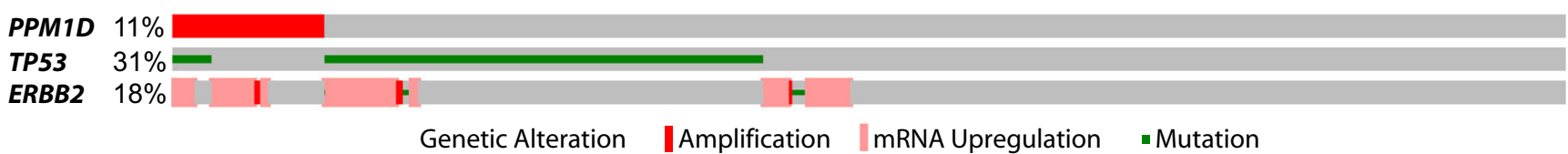

Fig. 2 Amplification of $P P M 1 D$ locus in breast cancer. Breast invasive carcinoma dataset $(n=817,[48])$ was analyzed for $P P M 1 D$ amplification (11\%), TP53 mutation (31\%), and ERBB2 amplification, overexpression, or mutation (18\%) using cBioPortal [49]. Amplification of genes was analyzed using putative copy number alterations from GISTIC.

cooperatively promote breast cancer development [70]. Ablation of PPM1D in mice impaired spermatogenesis and decreased levels of $\mathrm{B}$ and $\mathrm{T}$ lymphocytes, both probably reflecting the decreased ability to respond adequately to endogenous DNA breaks occurring during meiosis or immunoglobulin gene rearrangements, respectively [71, 72]. Importantly, deletion of PPM1D strongly suppressed breast tumorigenesis in mice bearing MMTV-driven oncogenes $E R B B 2$ or $H R A S 1$ through the inactivation of $\mathrm{p} 38$ MAPK and p53 pathways [73]. Loss of PPM1D also dramatically delayed development of E $\mu$-myc-induced lymphomas in a p53-dependent manner [74]. In context of the colon, WIP1 was found to be highly expressed in the stem cell compartment and loss of PPMID suppressed APC(Min)-driven polyp formation in mice suggesting that WIP1 might be involved also in development of colorectal cancer [75].

Exact molecular mechanism(s) by which WIP1 contributes to cell transformation still needs to be fully addressed. Data from the PPMID knock-out mice and clinical specimens suggest a strong correlation between oncogenic behavior of WIP1 and the functional p53 pathway. In addition, gain-of-function mutations in PPMID promote cell proliferation by overcoming p53 function, and conversely, loss of PPM1D slows down proliferation only in $\mathrm{p} 53$-proficient cells further supporting the model in which active WIP1 allows cells to overcome the tumor-suppressing barrier imposed by p53 pathway (Fig. 3). Whereas overexpressed WIP1 may not be sufficient to fully transform the cells, it can become more important under conditions of activation of oncogenes. It is well established that oncogene activation causes replication stress and induces senescence. An attractive possibility is that WIP1 may prevent oncogene-induced senescence and thus allow accumulation of mutations caused by proliferation under condition of replication stress. In addition, WIP1 was reported to regulate epigenetic changes in heterochromatin which may increase the Cto-T substitutions and thus contribute to genome instability [76]. Finally, overexpressed WIP1 was shown to impair DNA repair through nucleotide excision and base excision pathways $[77,78]$. It should be noted that all these mechanisms by which WIP1 activity promotes genome instability are not mutually exclusive, and they may jointly contribute to tumorigenesis.
Expression analysis was based on mRNA Expression z scores (RNA Seq V2 RSEM) where threshold was set at fourfold difference. Tendency to mutual exclusivity between PPMID and TP53 mutation as well as tendency to co-occurrence between PPMID and ERBB2 activation were statistically significant

\section{Predicted structure of WIP1 phosphatase}

Development of highly potent and specific small-molecule inhibitors is greatly facilitated by 3D structural data of the target proteins [79]. Since WIP1 structure has still not been determined, molecular models based on its homology with PPM1A (sharing 35\% sequence identity) represent the only resource of information about WIP1 structure [80, 81]. Like the other PP2Cs, WIP1 acts as monomer consisting of the Nterminal catalytic domain (amino acids 1-375) and a presumably unstructured C-terminal tail [82]. Conserved negatively charged amino acids in the catalytic domain bind two $\mathrm{Mg}^{2+}$ / $\mathrm{Mn}^{2+}$ ions and stabilize interaction of WIP1 with the phosphorylated substrate. A unique flap sub-domain resides in the catalytic domain close to the active site and can influence binding of different substrates by allosteric modulation [80]. Part of the flap domain is a basic amino acid-rich region (called B-loop; amino acids 235-268) that was proposed to bind to negatively charged phosphate on substrates [81]. In vitro studies established that WIP1 can specifically recognize two distinct substrate motifs, namely $\mathrm{pSQ} / \mathrm{pTQ}$ (present in ATM, p53, MDM2, $\gamma \mathrm{H} 2 \mathrm{AX}$, Chk1, Chk2) and pTxpY (present in the active form of p38 MAPK) [8]. In comparison to other PP2Cs, catalytic domain of WIP1 contains a prolinerich region (Pro-loop) that was proposed to mediate proteinprotein interactions. However, the Pro-loop is not evolutionary conserved and its function in control of WIP1 activity still remains unclear. Translocation of WIP1 to the nucleus is controlled by two nuclear localization sequences (NLS). One NLS resides in the C-terminus (amino acids 535-552), while the other is located within the catalytic domain (amino acids 247-250) [62, 83]. Presence of the two NLS sequences explains why the C-terminally truncated mutants of WIP1 localize normally in the nucleus.

\section{Small-molecule inhibitors of WIP1}

Based on data from PPM1D knockout mice and also from RNAi-mediated depletion of WIP1 in cancer cell lines, WIP1 was proposed as potential pharmacological target [73-75]. Since the structure of WIP1 is still unknown, the potential inhibitors of WIP1 were found by high-throughput 


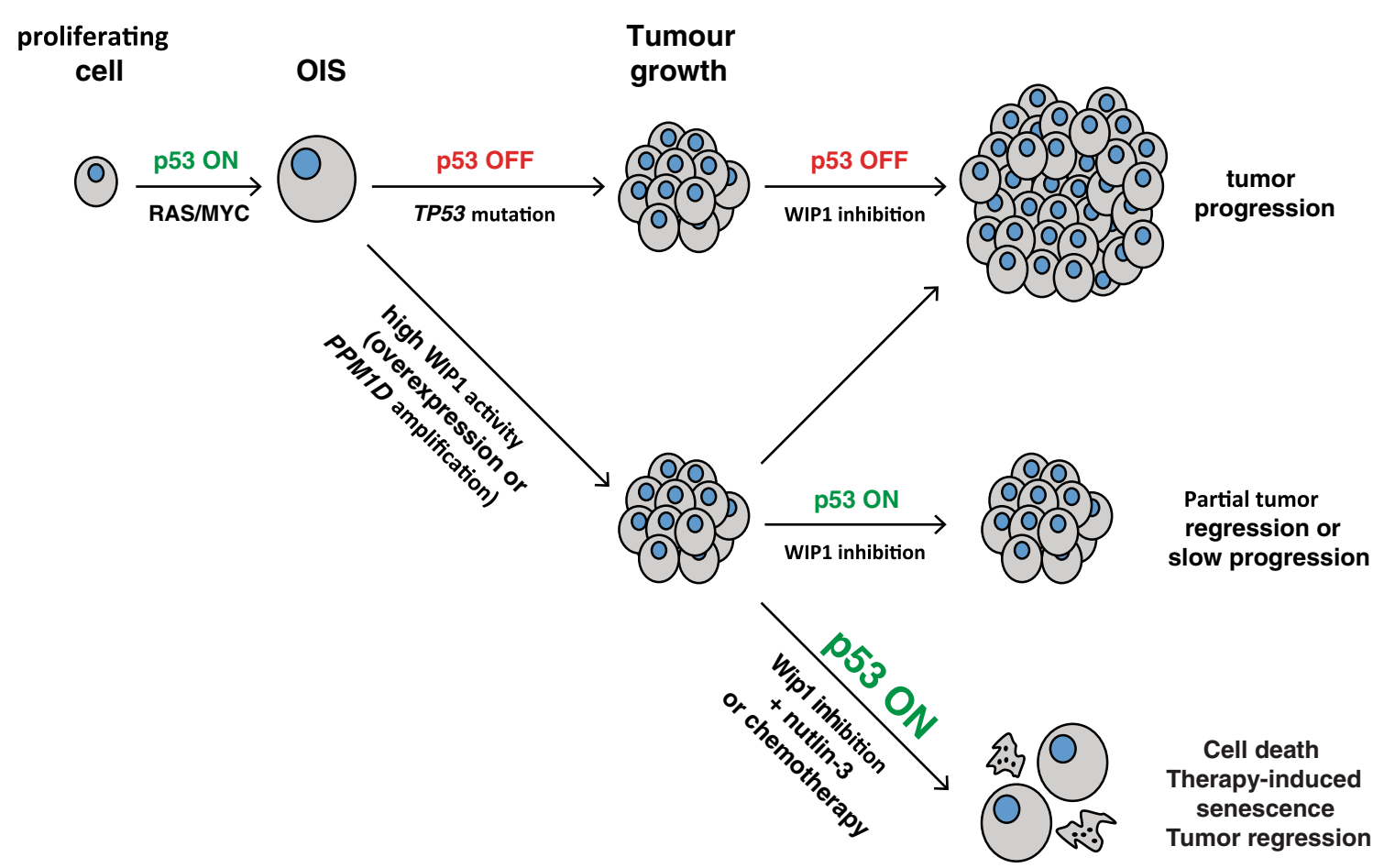

Fig. 3 Model for WIP1 involvement in tumorigenesis and in therapeutic response. Activation of oncogenes (such as $R A S$ and $M Y C$ ) causes replication stress, stimulates p53 activity, and results in permanent cell cycle arrest called oncogene-induced senescence (OIS). Inactivating mutation of TP53, overexpression of WIP1, or amplification of PPM1D leads to suppression of $\mathrm{p} 53$ pathway, disables establishment of OIS, and promotes tumor formation. Inhibition of WIP1 does not affect proliferation of cancer cells with mutant TP53 whereas it allows partial reactivation of $\mathrm{p} 53$ pathway in cells with wild-type TP53 slowing down their proliferation. Combination of WIP1 inhibition with MDM2 antagonist nutlin-3 or with DNA damage-inducing chemotherapy allows maximal activation of $\mathrm{p} 53$ pathway leading to induction of cell death or senescence and preventing tumor growth screening of extensive chemical libraries. During the last decade, several compounds antagonizing WIP1 activity were developed; however, only one of these inhibitors exhibits high specificity to WIP1 and shows promising results in preclinical analysis.

Inorganic compound arsenic trioxide (ATO) was shown to inhibit WIP1 in vitro $\left(\mathrm{IC}_{50}>100 \mu \mathrm{M}\right)$ and WIP1 depletion promoted ATO-induced apoptosis, probably by enhancing activation of Chk2/p53 and p38 pathways [84]. However, other studies demonstrated that ATO induced apoptosis by targeting multiple signal transduction pathways, suggesting that its selectivity to WIP1 is low [85]. Compound M321237 was identified by screening of a chemical library based on its ability to inhibit WIP1 activity in vitro [86]. Cell viability assay showed that M321237 sensitized MCF7 cells to doxorubicin. In vivo experiments reveled that administration of M321237 decreased tumor volumes in xenograft models; however, the selectivity of M321237 towards WIP1 has never been validated. Similar screening approach led to identification of CCT007093 that inhibited WIP1 in vitro with $\mathrm{IC}_{50}=8.4 \mu \mathrm{M}$ [87]. Cell viability in the presence of CCT007093 was suppressed in p53proficient cancer cells carrying amplified PPM1D [87]. On the other hand, CCT007093 suppressed UV-induced apoptosis in skin keratinocytes by preventing activation of JNK, suggesting low specificity of the inhibitor towards WIP1 [88]. In addition, CCT007093 was shown to suppress cell proliferation regardless of the presence of WIP1 in U2OS cells confirming an off-target effect of the inhibitor [89]. Further, treatment of cells with CCT007093 did not affect levels of p53-pS15 and $\gamma \mathrm{H} 2 \mathrm{AX}$, both well-established substrates of WIP1 [89]. These data suggest that CCT007093 does not inhibit WIP1 in cells and highlight the urgent need for validation of specificity of small-molecule inhibitors in cellular models including the CRISPR/Cas9-mediated knock-out of the expected target gene.

Compared to previous compounds, SPI-001 and its analogue SL-176 were determined as non-competitive inhibitors of recombinant WIP1 with $\mathrm{IC}_{50}=110$ and $86.9 \mathrm{nM}$, respectively $[90,91]$. Moreover, SPI-001 was determined to be approximately 50-fold more specific against WIP1 than to another PP2C phosphatase, PPM1A [90]. Both SPI-001 and SL176 suppressed the cell proliferation in human breast cancer MCF7 cells with overexpressed wild-type PPM1D in a dosedependent manner [91]. In human colorectal carcinoma HCT116 cells expressing truncated WIP1, treatment with SPI-001 did not affect cell proliferation but combined treatment with SPI-001 and doxorubicin enhanced inhibition of cell growth through the increased phosphorylation of p53 at Ser15 [92]. In 
conclusion, SPI-001 and SL-176 are promising lead compounds but further analysis is needed to validate their specificity and efficiency in cellular and animal models. Another strategy for development of WIP1 inhibitors was based on modification of short peptides derived from natural WIP1 substrates $[8,93,94]$. Substitution of the pT to $\mathrm{pS}$ in the pT$\mathrm{X}-\mathrm{pY}$ peptide sequence corresponding to $\mathrm{p} 38$ prevented its dephosphorylation by WIP1. Further modification led to development of a cyclic thioether peptide c(MpSIpYVA) with micro-molar inhibitory activity towards WIP1 $(\mathrm{Ki}=5 \mu \mathrm{M})$. These cyclic peptide inhibitors mimic substrates of WIP1 and block its enzymatic activity in vitro. Further improved cyclic peptide (F-pHse-I-pY-DDC-amide) significantly increased the inhibitory activity and selectivity for WIP1 with $\mathrm{Ki}=2.9 \mu \mathrm{M}$ [93]. The disadvantage of this peptide is poor bioavailability resulting in weak absorption into cells [95]. Therefore, phosphopeptide-based inhibitors have not been tested in cell viability assays to address their anti-proliferative effect. However, the cyclic peptide could be used in future in different drug delivery system, such as nanoparticles.

The most promising compound with high selectivity to WIP1 phosphatase was identified by combination of biochemical and biophysical screens that employed inhibition of WIP1 enzymatic activity and high-affinity binding as readouts, respectively [80]. Both screens identified compounds with overlapping structures containing an amino acid-like core region (referred to as capped amino acids, CAA) flanked by additional groups that influence pharmacokinetic properties [80]. From this series, compound GSK2830371 has been further developed and showed improved cell permeability and pharmacokinetics. According to WIP1 homology model with PPM1A structure and by photo-affinity labeling of WIP1, the binding sites of CAA were located in the Flap domain outside of the active site thus resulting in allosteric inhibition of WIP1. GSK2830371 inhibited WIP1 in vitro with $\mathrm{IC}_{50}=13 \mathrm{nM}$. This compound selectively inhibited WIP1 phosphatase while other 21 phosphatases showed no inhibition of enzyme activity in vitro. Cell proliferation experiments revealed that GSK2830371 efficiently suppressed proliferation of tumor cells carrying PPM1D amplification while retaining wild-type TP53, including hematological cancer, neuroblastoma, and breast cancer cell lines [57, 80, 89, 96, 97]. Importantly, U2OS-PPM1D-KO cells where PPM1D was knocked-out by CRISPR/Cas9 did not respond to GSK2830371 further confirming its specificity to WIP1 at cellular level [89]. Inhibition of WIP1 by GSK2830371 upregulated expression of p53 target genes including CDKN1A, PUMA, and BAX and caused cell cycle arrest but was not sufficient to induce cell death $[80,89,96,98]$. In addition, GSK2830371 suppressed growth of B cell lymphoma and neuroblastoma in xenograft mouse models demonstrating efficiency of this compound in vivo $[80,96]$. Importantly, these studies also demonstrated that GSK2830371 is orally bioavailable. However, relatively low stability of GSK2830371 in blood could limit its clinical use. Further modification of GSK2830371 as a lead compound will hopefully allow development of a small-molecule WIP1 inhibitor with more favorable pharmacokinetic properties.

\section{Targeting of WIP1 phosphatase in cancer therapy}

Restoration of $\mathrm{p} 53$ function was shown to cause tumor regression in a mouse model setting ground for development of various compounds capable of inducing the p53 pathway in cancer cells [99]. As described above, inhibition of WIP1 can suppress proliferation of cancer cells by activation of $\mathrm{p} 53$ pathway. The highest response is observed in cancer cells with the amplified PPM1D (such as MCF7) or truncated WIP1 (such as U2OS), suggesting that these cells might be addicted to the high level of WIP1. In contrast, healthy cells with basal expression of WIP1 are relatively resistant to WIP1 inhibition. Although inhibition of WIP1 strongly suppressed proliferation of cells with high activity of WIP1, it failed to induce massive cell death of cancer cells that would be desirable in cancer therapy $[80,89]$. Several studies showed that depletion of WIP1 by RNA interference sensitized cancer cells to DNA damage-inducing chemotherapy $[92,100,101]$. Similarly, GSK2830371 potentiated cytotoxic effect of doxorubicin in breast cancer cells, neuroblastoma, and lymphoma [89, 96, 97]. These results suggest that treatment with WIP1 inhibitor could allow to decrease the efficient dose of doxorubicin and thus reduce its undesired side effects $[102,103]$. Similarly, inhibition of WIP1 increased sensitivity of cells to ionizing radiation and to etoposide suggesting that a broader range of potentially beneficial treatment combinations may exist.

Reactivation of the p53 pathway by MDM2 inhibition has been suggested as a promising therapeutic strategy in cancers retaining wild-type TP53 and several MDM2 antagonists are currently in clinical trials [104-107]. MDM2 antagonist nutlin-3 and its orally bioavailable analogues RG7388 and RG7112 disrupted interaction between p53 and MDM2 leading to stabilization of p53 [108, 109]. MDM2 antagonists efficiently induced apoptosis in p53-proficient neuroblastoma and ovarian clear cell carcinoma and blocked tumor growth in xenograft models [109-112]. Combined treatment with GSK2830371 and nutlin-3 further increased the level of p53 pathway activation and potentiated induction of senescence and apoptosis in MCF7 and HCT116 cells [89, 97, 98, 113]. These data suggest that inhibition of WIP1 that leads to increased phosphorylation of $\mathrm{p} 53$ may synergize with compounds that promote stabilization of $\mathrm{p} 53$. Besides nutlin-3, other MDM2 antagonists were reported to reactivate p53 and to strongly induce apoptosis of cancer cells, including RITA that binds to p53 at its N-terminus. Whereas the specificity of nutlin-3 has recently been confirmed by CRISPR/ Cas9-mediated deletion of p53, cytotoxic effect of RITA was 
completely independent on the presence of $\mathrm{p} 53$, further highlighting the need for validation of the small-molecule inhibitors using modern gene-targeting approaches [114].

\section{WIP1 activation in 153 negative tumors}

As described above, WIP1 is a major negative regulator of p53 pathway. Besides direct or indirect inactivation of p53 pathway, WIP1 was reported to control the expression level of a pro-apoptotic protein Bax through dephosphorylation of a transcriptional factor RUNX2 $[115,116]$. This pathway is particularly important in p53-negative cancer cells, where WIP1 activity promotes cisplatin-induced apoptosis. These results led to postulation of an attractive model in which activation of WIP1 can increase sensitivity of p53-negative cells to chemotherapy while protecting the healthy cells (carrying wild-type p53) from possible side effects. However, until now, selective potentiation of WIP1 function remains challenging. One of the possibilities for pharmaceutical intervention could be regulation of WIP1 stability in cells. Turnover of WIP1 in cells is relatively fast (half-life about $90 \mathrm{~min}$ ) and phosphorylation of WIP1 by HIPK2 potentiates its degradation by proteasome [117]. Indeed, depletion of HIPK2 enhanced the stability of WIP1 and recently has been reported to increase the sensitivity of p53-deficient Saos2 cells to cisplatin [117, 118]. It will be interesting to address the ability of pharmacological inhibitors of HIPK2 to modulate WIP1 levels in cells. Another possibility to increase WIP1 levels in cells might be selective induction of PPM1D expression, possibly by RNA-guided activation of endogenous human genes [119]. Clearly, more research is needed to explore suitable approaches for selective WIP1 induction and to experimentally test its benefit for eradication of p53-negative tumors.

\section{Role of WIP1 in immune response and hematopoiesis}

Besides well-established roles of WIP1 in regulation of stress response pathways, there is emerging evidence implicating WIP1 in differentiation of hematopoietic progenitors and in the immune response (recently reviewed in $[120,121])$. In particular, PPM1D knock-out mice show a p53-dependent block in T cell and B cell maturation in the thymus and bone marrow, respectively $[122,123]$. In addition, WIP1 is highly expressed in various kinds of stem cells, and PPMID knockout mice show increased apoptosis in stem cell compartments $[33,75,124]$. Interestingly, apoptosis in WIP1-deficient intestinal and mesenchymal stem cells was rescued by loss of $\mathrm{p} 53$, whereas apoptosis of hematopoietic stem cells (HSC) was p53 independent $[33,75,124]$. Loss of WIP1 led to hyperproliferation of HSC due to the activation of MTORC1 pathway and led to premature exhaustion of HSC [124]. On the other hand, deletion of $\mathrm{p} 53$ rescued the differentiation of WIP1-deficient HSCs into erythroid and myeloid lineages and the repopulation defect in lethally irradiated mice [124]. Finally, mice lacking WIP1 showed increased number of neutrophils and were prone to chronic inflammation such as the DSS-induced colitis $[41,125]$. Whereas some of the defects in the immune response observed in WIP1 deficient mice can be explained by abnormal activation of the p53 pathway, others are likely p53 independent. More research is needed to identify molecular mechanisms by which WIP1 regulates the activity of NFKB and mTORC pathways and production of cytokines during the immune response.

\section{Conclusions and future directions}

Data from cell biology and mouse genetics highlight WIP1 as an important negative regulator of p53 pathway and a terminator of the DNA damage response. When overexpressed, WIP1 impairs $\mathrm{p} 53$ function and contributes to tumorigenesis, usually in combination with activation of other oncogenes. Conversely, loss of WIP1 significantly delays tumor development in mice and similarly depletion of WIP1 by RNA interference allows reactivation of $\mathrm{p} 53$ pathway and inhibits proliferation in $\mathrm{p} 53$-proficient tumors. Until recently, specific inhibition of WIP1 represented a major challenge and lack of selective small-molecule inhibitors limited exploitation of WIP1 as pharmacological target in cancer therapy. Situation has changed by development of the compound GSK2830371 that has validated specificity towards WIP1 and efficiently reactivates p53 pathway in various cancer types, including breast cancer, neuroblastoma, and lymphoma. In combination with DNA damage-inducing chemotherapy or with MDM2 antagonists (such as nutlin-3), WIP1 inhibition promotes cancer cell death or senescence, while it has little effect on viability of healthy cells. Importantly, GSK2830371 is orally bioavailable and its ability to suppress cancer cell growth in vivo was demonstrated in xenograft models. In the same time, GSK2830371 is rapidly inactivated in plasma, which may limit its further clinical use. Therefore, further development of GSK2830371 derivatives with more favorable pharmacokinetic properties is highly desirable. Also, solving the 3D structure of WIP1 could stimulate development of even more selective WIP1 inhibitors. Current results suggest that inhibition of WIP1 will be most efficient in cancers with wild-type p53 and amplification or gain-offunction mutations of $P P M 1 D$, and thus, determination of the status of TP53 and PPM1D in the tumors will be important for predicting the therapeutical outcome of WIP1 inhibitors. Identification of additional factors that control the ability of cells to reactivate p53 pathway is needed to allow prediction of the cancer cell sensitivity to WIP1 
inhibitors. MDM2 and MDMX that are commonly overexpressed in tumors seem to be attractive candidates for testing the sensitivity to MDM2 antagonists and WIP1 inhibitors. Although loss of WIP1 is well tolerated in mice, there is emerging evidence that WIP1 plays a role in differentiation of cells of the immune system. In light of these newly arising physiological roles of WIP1, it will be important to address possible side effects of a temporary inhibition of WIP1 during therapeutical intervention.

Acknowledgements This work was supported by Norwegian Financial Mechanism 2009-2014 (PHOSCAN, 7F14061) and by Ministry of Education Youth and Sports (CZ-OPENSCREEN, LO1220).

Conflict of interest The authors declare that they have no conflict of interest.

Open Access This article is distributed under the terms of the Creative Commons Attribution 4.0 International License (http:// creativecommons.org/licenses/by/4.0/), which permits unrestricted use, distribution, and reproduction in any medium, provided you give appropriate credit to the original author(s) and the source, provide a link to the Creative Commons license, and indicate if changes were made.

\section{References}

1. Jackson SP, Bartek J (2009) The DNA-damage response in human biology and disease. Nature 461:1071-1078

2. Halazonetis TD, Gorgoulis VG, Bartek J (2008) An oncogeneinduced DNA damage model for cancer development. Science 319:1352-1355

3. Bartek J, Bartkova J, Lukas J (2007) DNA damage signalling guards against activated oncogenes and tumour progression. Oncogene 26:7773-7779

4. Bartkova J, Horejsi Z, Koed K, Kramer A, Tort F, Zieger K, Guldberg P, Sehested M, Nesland JM, Lukas C et al (2005) DNA damage response as a candidate anti-cancer barrier in early human tumorigenesis. Nature 434:864-870

5. Polo SE, Jackson SP (2011) Dynamics of DNA damage response proteins at DNA breaks: a focus on protein modifications. Genes Dev 25:409-433

6. Lammers T, Lavi S (2007) Role of type 2C protein phosphatases in growth regulation and in cellular stress signaling. Crit Rev Biochem Mol Biol 42:437-461

7. Fiscella M, Zhang H, Fan S, Sakaguchi K, Shen S, Mercer WE, Vande Woude GF, O'Connor PM, Appella E (1997) Wip1, a novel human protein phosphatase that is induced in response to ionizing radiation in a p53-dependent manner. Proc Natl Acad Sci U S A 94:6048-6053

8. Yamaguchi H, Minopoli G, Demidov ON, Chatterjee DK, Anderson CW, Durell SR, Appella E (2005) Substrate specificity of the human protein phosphatase 2Cdelta, Wip1. Biochemistry 44:5285-5294

9. Macurek L, Lindqvist A, Voets O, Kool J, Vos HR, Medema RH (2010) Wip1 phosphatase is associated with chromatin and dephosphorylates gammaH2AX to promote checkpoint inhibition. Oncogene 29:2281-2291
10. Lu X, Nannenga B, Donehower LA (2005) PPM1D dephosphorylates Chk1 and p53 and abrogates cell cycle checkpoints. Genes Dev 19:1162-1174

11. Lindqvist A, de Bruijn M, Macurek L, Bras A, Mensinga A, Bruinsma W, Voets O, Kranenburg O, Medema RH (2009) Wip1 confers G2 checkpoint recovery competence by counteracting p53-dependent transcriptional repression. EMBO J 28:3196-3206

12. Lu X, Nguyen TA, Moon SH, Darlington Y, Sommer M, Donehower LA (2008) The type 2C phosphatase Wip1: an oncogenic regulator of tumor suppressor and DNA damage response pathways. Cancer Metastasis Rev 27:123-135

13. Le Guezennec X, Bulavin DV (2010) WIP1 phosphatase at the crossroads of cancer and aging. Trends Biochem Sci 35:109-114

14. Harrison M, Li J, Degenhardt Y, Hoey T, Powers S (2004) Wip1deficient mice are resistant to common cancer genes. Trends $\mathrm{Mol}$ Med 10:359-361

15. Leslie PL, Zhang Y (2016) MDM2 oligomers: antagonizers of the guardian of the genome. Oncogene. doi:10.1038/onc.2016.88

16. Haupt Y, Maya R, Kazaz A, Oren M (1997) Mdm2 promotes the rapid degradation of $\mathrm{p} 53$. Nature 387:296-299

17. Pei D, Zhang Y, Zheng J (2012) Regulation of p53: a collaboration between Mdm2 and Mdmx. Oncotarget 3:228-235

18. Honda R, Tanaka H, Yasuda H (1997) Oncoprotein MDM2 is a ubiquitin ligase E3 for tumor suppressor p53. FEBS Lett 420:25-27

19. Zhang XP, Liu F, Cheng Z, Wang W (2009) Cell fate decision mediated by p53 pulses. Proc Natl Acad Sci U S A 106:12245-12250

20. Leontieva OV, Gudkov AV, Blagosklonny MV (2010) Weak p53 permits senescence during cell cycle arrest. Cell Cycle 9:4323-4327

21. Lee Y-K, Thomas SN, Yang AJ, Ann DK (2007) Doxorubicin downregulates Krüppel-associated box domain-associated protein 1 sumoylation that relieves its transcription repression on p21WAF1/ CIP1 in breast cancer MCF-7 cells. J Biol Chem 282:1595-1606

22. Blasius M, Forment JV, Thakkar N, Wagner SA, Choudhary C, Jackson SP (2011) A phospho-proteomic screen identifies substrates of the checkpoint kinase Chk1. Genome Biol 12:R78-R78

23. Chapman JR, Taylor Martin RG, Boulton Simon J (2012) Playing the end game: DNA double-strand break repair pathway choice. Mol Cell 47:497-510

24. Mamely I, van Vugt MATM, Smits VAJ, Semple JI, Lemmens B, Perrakis A, Medema RH, Freire R (2006) Polo-like kinase-1 controls proteasome-dependent degradation of claspin during checkpoint recovery. Curr Biol 16:1950-1955

25. Shaltiel IA, Krenning L, Bruinsma W, Medema RH (2015) The same, only different - DNA damage checkpoints and their reversal throughout the cell cycle. J Cell Sci 128:607-620

26. Shaltiel IA, Aprelia M, Saurin AT, Chowdhury D, Kops GJ, Voest EE, Medema RH (2014) Distinct phosphatases antagonize the p53 response in different phases of the cell cycle. Proc Natl Acad Sci U S A 111:7313-7318

27. Lu X, Nguyen TA, Zhang X, Donehower LA (2008) The Wip1 phosphatase and Mdm2: cracking the "Wip" on p53 stability. Cell Cycle 7:164-168

28. Lu X, Ma O, Nguyen TA, Jones SN, Oren M, Donehower LA (2007) The Wip1 phosphatase acts as a gatekeeper in the p53Mdm2 autoregulatory loop. Cancer Cell 12:342-354

29. Zhang X, Lin L, Guo H, Yang J, Jones SN, Jochemsen A, Lu X (2009) Phosphorylation and degradation of MdmX is inhibited by Wip1 phosphatase in the DNA damage response. Cancer Res 69: 7960-7968

30. Meulmeester E, Pereg Y, Shiloh Y, Jochemsen AG (2005) ATMmediated phosphorylations inhibit $\mathrm{Mdmx} / \mathrm{Mdm} 2$ stabilization by HAUSP in favor of p53 activation. Cell Cycle 4:1166-1170

31. Krenning L, Feringa Femke M, Shaltiel Indra A, van den Berg J, Medema René $\mathrm{H}$ (2014) Transient activation of p53 in G2 phase is sufficient to induce senescence. Mol Cell 55:59-72 
32. Müllers E, Cascales HS, Jaiswal H, Saurin AT, Lindqvist A (2014) Nuclear translocation of cyclin B1 marks the restriction point for terminal cell cycle exit in G2 phase. Cell Cycle 13:2733-2743

33. Lee JS, Lee MO, Moon BH, Shim SH, Fornace AJ Jr, Cha HJ (2009) Senescent growth arrest in mesenchymal stem cells is bypassed by Wip1-mediated downregulation of intrinsic stress signaling pathways. Stem Cells 27:1963-1975

34. Sakai H, Fujigaki H, Mazur SJ, Appella E (2014) Wild-type p53-induced phosphatase 1 (Wip1) forestalls cellular premature senescence at physiological oxygen levels by regulating DNA damage response signaling during DNA replication. Cell Cycle 13:1015-1029

35. Song JY, Ryu SH, Cho YM, Kim YS, Lee BM, Lee SW, Choi J (2013) Wip1 suppresses apoptotic cell death through direct dephosphorylation of BAX in response to gamma-radiation. Cell Death Dis 4:e744

36. Shreeram S, Demidov ON, Hee WK, Yamaguchi H, Onishi N, Kek C, Timofeev ON, Dudgeon C, Fornace AJ, Anderson CW et al (2006) Wip1 phosphatase modulates ATM-dependent signaling pathways. Mol Cell 23:757-764

37. Moon SH, Lin L, Zhang X, Nguyen TA, Darlington Y, Waldman AS, Lu X, Donehower LA (2010) Wild-type p53-induced phosphatase 1 dephosphorylates histone variant gamma-H2AX and suppresses DNA double strand break repair. J Biol Chem 285: 12935-12947

38. Cha H, Lowe JM, Li H, Lee JS, Belova GI, Bulavin DV, Fornace AJ Jr (2010) Wip1 directly dephosphorylates gamma-H2AX and attenuates the DNA damage response. Cancer Res 70:4112-4122

39. Yoda A, Xu XZ, Onishi N, Toyoshima K, Fujimoto H, Kato N, Oishi I, Kondo T, Minami Y (2006) Intrinsic kinase activity and $\mathrm{SQ} / \mathrm{TQ}$ domain of Chk2 kinase as well as N-terminal domain of Wip1 phosphatase are required for regulation of Chk2 by Wip1. J Biol Chem 281:24847-24862

40. Takekawa M, Adachi M, Nakahata A, Nakayama I, Itoh F, Tsukuda H, Taya Y, Imai K (2000) p53-inducible wip1 phosphatase mediates a negative feedback regulation of p38 MAPK-p53 signaling in response to UV radiation. EMBO J 19:6517-6526

41. Chew J, Biswas S, Shreeram S, Humaidi M, Wong ET, Dhillion MK, Teo H, Hazra A, Fang CC, Lopez-Collazo E et al (2009) WIP1 phosphatase is a negative regulator of NF-[kappa]B signalling. Nat Cell Biol 11:659-666

42. Macurek L, Benada J, Mullers E, Halim VA, Krejcikova K, Burdova K, Pechackova S, Hodny Z, Lindqvist A, Medema RH et al (2013) Downregulation of Wip1 phosphatase modulates the cellular threshold of DNA damage signaling in mitosis. Cell Cycle $12: 251-262$

43. Choi Dong W, Na W, Kabir Mohammad H, Yi E, Kwon S, Yeom J, Ahn J-W, Choi H-H, Lee Y, Seo Kyoung W et al (2013) WIP1, a homeostatic regulator of the DNA damage response, is targeted by HIPK2 for phosphorylation and degradation. Mol Cell 51(3):374-385

44. Petitjean A, Achatz MIW, Borresen-Dale AL, Hainaut P, Olivier M (2007) TP53 mutations in human cancers: functional selection and impact on cancer prognosis and outcomes. Oncogene 26: 2157-2165

45. Wang X, Sun Q (2016) TP53 mutations, expression and interaction networks in human cancers. Oncotarget. doi:10.18632/ oncotarget. 13483

46. Natrajan R, Lambros MB, Rodríguez-Pinilla SM, Moreno-Bueno G, Tan DSP, Marchió C, Vatcheva R, Rayter S, Mahler-Araujo B, Fulford LG et al (2009) Tiling path genomic profiling of grade 3 invasive ductal breast cancers. Clin Cancer Res 15:2711

47. Li J, Yang Y, Peng Y, Austin RJ, van Eyndhoven WG, Nguyen KC, Gabriele T, McCurrach ME, Marks JR, Hoey T et al (2002) Oncogenic properties of PPM1D located within a breast cancer amplification epicenter at 17q23. Nat Genet 31:133-134
48. Ciriello G, Gatza Michael L, Beck Andrew H, Wilkerson Matthew D, Rhie Suhn K, Pastore A, Zhang H, McLellan M, Yau C, Kandoth $\mathrm{C}$ et al Comprehensive molecular portraits of invasive lobular breast cancer. Cell 163:506-519

49. Gao J, Aksoy BA, Dogrusoz U, Dresdner G, Gross B, Sumer SO, Sun Y, Jacobsen A, Sinha R, Larsson E et al (2013) Integrative analysis of complex cancer genomics and clinical profiles using the cBioPortal. Sci Signal 6:pl1-pl1

50. Shih-Chu Ho E, Lai C-R, Hsieh Y-T, Chen J-T, Lin A-J, Hung MJ, Liu F-S (2001) p53 mutation is infrequent in clear cell carcinoma of the ovary. Gynecol Oncol 80:189-193

51. Tan DS, Lambros MB, Rayter S, Natrajan R, Vatcheva R, Gao Q, Marchio C, Geyer FC, Savage K, Parry S et al (2009) PPM1D is a potential therapeutic target in ovarian clear cell carcinomas. Clin Cancer Res 15:2269-2280

52. Bulavin DV, Demidov ON, Saito S, Kauraniemi P, Phillips C, Amundson SA, Ambrosino C, Sauter G, Nebreda AR, Anderson CW et al (2002) Amplification of PPM1D in human tumors abrogates p53 tumor-suppressor activity. Nat Genet 31:210-215

53. Liang C, Guo E, Lu S, Wang S, Kang C, Chang L, Liu L, Zhang G, Wu Z, Zhao Z et al (2012) Over-expression of wild-type p53induced phosphatase 1 confers poor prognosis of patients with gliomas. Brain Res 1444:65-75

54. Rauta J, Alarmo EL, Kauraniemi P, Karhu R, Kuukasjarvi T, Kallioniemi A (2006) The serine-threonine protein phosphatase PPM1D is frequently activated through amplification in aggressive primary breast tumours. Breast Cancer Res Treat 95:257-263

55. Peng TS, He YH, Nie T, Hu XD, Lu HY, Yi J, Shuai YF, Luo M (2014) PPM1D is a prognostic marker and therapeutic target in colorectal cancer. Exp Ther Med 8:430-434

56. Castellino RC, De Bortoli M, Lu X, Moon SH, Nguyen TA, Shepard MA, Rao PH, Donehower LA, Kim JY (2008) Medulloblastomas overexpress the p53-inactivating oncogene WIP1/PPM1D. J Neuro-Oncol 86:245-256

57. Richter M, Dayaram T, Gilmartin AG, Ganji G, Pemmasani SK, Van Der Key H, Shohet JM, Donehower LA, Kumar R (2015) WIP1 phosphatase as a potential therapeutic target in neuroblastoma. PLoS One 10:e115635

58. Saito-Ohara F, Imoto I, Inoue J, Hosoi H, Nakagawara A, Sugimoto T, Inazawa J (2003) PPM1D is a potential target for 17q gain in neuroblastoma. Cancer Res 63:1876-1883

59. Satoh N, Maniwa Y, Bermudez VP, Nishimura K, Nishio W, Yoshimura M, Okita Y, Ohbayashi C, Hurwitz J, Hayashi Y (2011) Oncogenic phosphatase Wipl is a novel prognostic marker for lung adenocarcinoma patient survival. Cancer Sci 102:1101-1106

60. Fuku T, Semba S, Yutori H, Yokozaki H (2007) Increased wildtype p53-induced phosphatase 1 (Wip1 or PPM1D) expression correlated with downregulation of checkpoint kinase 2 in human gastric carcinoma. Pathol Int 57:566-571

61. Ruark E, Snape K, Humburg P, Loveday C, Bajrami I, Brough R, Rodrigues DN, Renwick A, Seal S, Ramsay E et al (2013) Mosaic PPM1D mutations are associated with predisposition to breast and ovarian cancer. Nature 493:406-410

62. Kleiblova P, Shaltiel IA, Benada J, Sevcik J, Pechackova S, Pohlreich P, Voest EE, Dundr P, Bartek J, Kleibl Z et al (2013) Gain-of-function mutations of PPM1D/Wip1 impair the p53dependent G1 checkpoint. J Cell Biol 201:511-521

63. Dudgeon C, Shreeram S, Tanoue K, Mazur SJ, Sayadi A, Robinson RC, Appella E, Bulavin DV (2013) Genetic variants and mutations of PPM1D control the response to DNA damage. Cell Cycle 12:2656-2664

64. Swisher EM, Harrell MI, Norquist BM et al (2016) Somatic mosaic mutations in ppm1d and tp53 in the blood of women with ovarian carcinoma. JAMA Oncology 2:370-372

65. Zhang L, Chen LH, Wan H, Yang R, Wang Z, Feng J, Yang S, Jones S, Wang S, Zhou W et al (2014) Exome sequencing 
identifies somatic gain-of-function PPM1D mutations in brainstem gliomas. Nat Genet 46:726-730

66. Zajkowicz A, Butkiewicz D, Drosik A, Giglok M, Suwinski R, Rusin M (2015) Truncating mutations of PPM1D are found in blood DNA samples of lung cancer patients. Br J Cancer 112: 1114-1120

67. Cardoso M, Paulo P, Maia S, Teixeira MR (2016) Truncating and missense PPM1D mutations in early-onset and/or familial/hereditary prostate cancer patients. Genes Chromosom Cancer 55:954-961

68. Yu E, Ahn YS, Jang SJ, Kim M-J, Yoon HS, Gong G, Choi J (2007) Overexpression of the wip1 gene abrogates the p38 MAPK/p53/Wip1 pathway and silences p16 expression in human breast cancers. Breast Cancer Res Treat 101:269-278

69. Demidov ON, Kek C, Shreeram S, Timofeev O, Fornace AJ, Appella E, Bulavin DV (2006) The role of the MKK6//p38 MAPK pathway in Wip1-dependent regulation of ErbB2-driven mammary gland tumorigenesis. Oncogene 26:2502-2506

70. Demidov ON, Kek C, Shreeram S, Timofeev O, Fornace AJ, Appella E, Bulavin DV (2007) The role of the MKK6/p38 MAPK pathway in Wip1-dependent regulation of ErbB2-driven mammary gland tumorigenesis. Oncogene 26:2502-2506

71. Choi J, Nannenga B, Demidov ON, Bulavin DV, Cooney A, Brayton C, Zhang Y, Mbawuike IN, Bradley A, Appella E et al (2002) Mice deficient for the wild-type p53-induced phosphatase gene (Wip1) exhibit defects in reproductive organs, immune function, and cell cycle control. Mol Cell Biol 22:1094-1105

72. Nannenga B, Lu X, Dumble M, Van Maanen M, Nguyen TA, Sutton R, Kumar TR, Donehower LA (2006) Augmented cancer resistance and DNA damage response phenotypes in PPM1D null mice. Mol Carcinog 45:594-604

73. Bulavin DV, Phillips C, Nannenga B, Timofeev O, Donehower LA, Anderson CW, Appella E, Fornace AJ Jr (2004) Inactivation of the Wip1 phosphatase inhibits mammary tumorigenesis through p38 MAPK-mediated activation of the p16(Ink4a)p19(Arf) pathway. Nat Genet 36:343-350

74. Shreeram S, Hee WK, Demidov ON, Kek C, Yamaguchi H, Fornace AJ Jr, Anderson CW, Appella E, Bulavin DV (2006) Regulation of ATM/p53-dependent suppression of myc-induced lymphomas by Wip1 phosphatase. J Exp Med 203:2793-2799

75. Demidov ON, Timofeev O, Lwin HN, Kek C, Appella E, Bulavin DV (2007) Wip1 phosphatase regulates p53-dependent apoptosis of stem cells and tumorigenesis in the mouse intestine. Cell Stem Cell 1:180-190

76. Filipponi D, Muller J, Emelyanov A, Bulavin DV (2013) Wip1 controls global heterochromatin silencing via ATM/BRCA1dependent DNA methylation. Cancer Cell 24:528-541

77. Nguyen TA, Slattery SD, Moon SH, Darlington YF, Lu X, Donehower LA (2010) The oncogenic phosphatase WIP1 negatively regulates nucleotide excision repair. DNA Repair (Amst) 9:813-823

78. Lu X, Bocangel D, Nannenga B, Yamaguchi H, Appella E, Donehower LA (2004) The p53-induced oncogenic phosphatase PPM1D interacts with uracil DNA glycosylase and suppresses base excision repair. Mol Cell 15:621-634

79. Zhang C, Lai L (2011) Towards structure-based protein drug design. Biochem Soc Trans 39:1382-1386 suppl 1381 p following 1386

80. Gilmartin AG, Faitg TH, Richter M, Groy A, Seefeld MA, Darcy MG, Peng X, Federowicz K, Yang J, Zhang SY et al (2014) Allosteric Wip1 phosphatase inhibition through flap-subdomain interaction. Nat Chem Biol 10:181-187

81. Chuman Y, Yagi H, Fukuda T, Nomura T, Matsukizono M, Shimohigashi Y, Sakaguchi K (2008) Characterization of the active site and a unique uncompetitive inhibitor of the PPM1-type protein phosphatase PPM1D. Protein Pept Lett 15:938-948

82. Nakagawa H, Wardell CP, Furuta M, Taniguchi H, Fujimoto A (2015) Cancer whole-genome sequencing: present and future. Oncogene 34:5943-5950
83. Chuman Y, Kurihashi W, Mizukami Y, Nashimoto T, Yagi H, Sakaguchi K (2009) PPM1D430, a novel alternative splicing variant of the human PPM1D, can dephosphorylate 553 and exhibits specific tissue expression. J Biochem 145:1-12

84. Yoda A, Toyoshima K, Watanabe Y, Onishi N, Hazaka Y, Tsukuda Y, Tsukada J, Kondo T, Tanaka Y, Minami Y (2008) Arsenic trioxide augments Chk2/p53-mediated apoptosis by inhibiting oncogenic Wip1 phosphatase. J Biol Chem 283:18969-18979

85. Miller WH, Schipper HM, Lee JS, Singer J, Waxman S (2002) Mechanisms of action of arsenic trioxide. Cancer Res 62:3893-3903

86. Belova GI, Demidov ON, Fornace AJ Jr, Bulavin DV (2005) Chemical inhibition of Wip1 phosphatase contributes to suppression of tumorigenesis. Cancer Biol Ther 4:1154-1158

87. Rayter S, Elliott R, Travers J, Rowlands MG, Richardson TB, Boxall K, Jones K, Linardopoulos S, Workman P, Aherne W et al (2008) A chemical inhibitor of PPM1D that selectively kills cells overexpressing PPM1D. Oncogene 27:1036-1044

88. Lee JS, Park JR, Kwon OS, Kim H, Fornace AJ Jr, Cha HJ (2014) Off-target response of a Wip1 chemical inhibitor in skin keratinocytes. J Dermatol Sci 73:125-134

89. Pechackova S, Burdova K, Benada J, Kleiblova P, Jenikova G, Macurek L (2016) Inhibition of WIP1 phosphatase sensitizes breast cancer cells to genotoxic stress and to MDM2 antagonist nutlin-3. Oncotarget 7(12):14458-14475

90. Yagi H, Chuman Y, Kozakai Y, Imagawa T, Takahashi Y, Yoshimura F, Tanino K, Sakaguchi K (2012) A small molecule inhibitor of p53-inducible protein phosphatase PPM1D. Bioorg Med Chem Lett 22:729-732

91. Ogasawara S, Kiyota Y, Chuman Y, Kowata A, Yoshimura F, Tanino K, Kamada R, Sakaguchi K (2015) Novel inhibitors targeting PPM1D phosphatase potently suppress cancer cell proliferation. Bioorg Med Chem 23:6246-6249

92. Kozakai Y, Kamada R, Kiyota Y, Yoshimura F, Tanino K, Sakaguchi $\mathrm{K}$ (2014) Inhibition of C-terminal truncated PPM1D enhances the effect of doxorubicin on cell viability in human colorectal carcinoma cell line. Bioorg Med Chem Lett 24:5593-5596

93. Hayashi R, Tanoue K, Durell SR, Chatterjee DK, Jenkins LM, Appella DH, Appella E (2011) Optimization of a cyclic peptide inhibitor of Ser/Thr phosphatase PPM1D (Wip1). Biochemistry 50:4537-4549

94. Yamaguchi H, Durell SR, Feng H, Bai Y, Anderson CW, Appella E (2006) Development of a substrate-based cyclic phosphopeptide inhibitor of protein phosphatase 2Cdelta, Wip1. Biochemistry 45: 13193-13202

95. Bang J, Yamaguchi H, Durell SR, Appella E, Appella DH (2008) A small molecular scaffold for selective inhibition of Wip1 phosphatase(). ChemMedChem 3. doi:10.1002/cmdc.200700281

96. Chen Z, Wang L, Yao D, Yang T, Cao WM, Dou J, Pang JC, Guan S, Zhang H, Yu Y et al (2016) Wip1 inhibitor GSK2830371 inhibits neuroblastoma growth by inducing Chk2/p53-mediated apoptosis. Sci Rep 6:38011

97. Kojima K, Maeda A, Yoshimura M, Nishida Y, Kimura S (2016) The pathophysiological significance of PPM1D and therapeutic targeting of PPM1D-mediated signaling by GSK2830371 in mantle cell lymphoma. Oncotarget. doi:10.18632/oncotarget.11904

98. Sriraman A, Radovanovic M, Wienken M, Najafova Z, Li Y, Dobbelstein M (2016) Cooperation of Nutlin-3a and a Wip1 inhibitor to induce p53 activity. Oncotarget 7:31623-31638

99. Ventura A, Kirsch DG, McLaughlin ME, Tuveson DA, Grimm J, Lintault L, Newman J, Reczek EE, Weissleder R, Jacks T (2007) Restoration of $\mathrm{p} 53$ function leads to tumour regression in vivo. Nature 445:661-665

100. Kong W, Jiang X, Mercer WE (2009) Downregulation of Wip-1 phosphatase expression in MCF-7 breast cancer cells enhances 
doxorubicin-induced apoptosis through p53-mediated transcriptional activation of Bax. Cancer Biol Ther 8:555-563

101. Ali AY, Abedini MR, Tsang BK (2012) The oncogenic phosphatase PPM1D confers cisplatin resistance in ovarian carcinoma cells by attenuating checkpoint kinase 1 and p53 activation. Oncogene 31:2175-2186

102. Rochette L, Guenancia C, Gudjoncik A, Hachet O, Zeller M, Cottin Y, Vergely C (2015) Anthracyclines/trastuzumab: new aspects of cardiotoxicity and molecular mechanisms. Trends Pharmacol Sci 36:326-348

103. Derek WE, Rashmi N, Simon C, Kyle M-B, Jonathan PJM, Amadeo MP (2015) Role of drug metabolism in the cytotoxicity and clinical efficacy of anthracyclines. Curr Drug Metab 16:412-426

104. Qin L, Yang F, Zhou C, Chen Y, Zhang H, Su Z (2014) Efficient reactivation of $\mathrm{p} 53$ in cancer cells by a dual MdmX/Mdm2 inhibitor. J Am Chem Soc 136:18023-18033

105. Brown CJ, Lain S, Verma CS, Fersht AR, Lane DP (2009) Awakening guardian angels: drugging the $\mathrm{p} 53$ pathway. Nat Rev Cancer 9:862-873

106. Khoo KH, Verma CS, Lane DP (2014) Drugging the $\mathrm{p} 53$ pathway: understanding the route to clinical efficacy. Nat Rev Drug Discov $13: 217-236$

107. Zhang Q, Zeng SX, Lu H (2014) Targeting p53-MDM2-MDMX loop for cancer therapy. Subcell Biochem 85:281-319

108. Vassilev LT, Vu BT, Graves B, Carvajal D, Podlaski F, Filipovic Z, Kong N, Kammlott U, Lukacs C, Klein C et al (2004) In vivo activation of the 533 pathway by small-molecule antagonists of MDM2. Science 303:844-848

109. Ding Q, Zhang Z, Liu JJ, Jiang N, Zhang J, Ross TM, Chu XJ, Bartkovitz D, Podlaski F, Janson C et al (2013) Discovery of RG7388, a potent and selective p53-MDM2 inhibitor in clinical development. J Med Chem 56:5979-5983

110. Chen L, Rousseau RF, Middleton SA, Nichols GL, Newell DR, Lunec J, Tweddle DA (2015) Pre-clinical evaluation of the MDM2-p53 antagonist RG7388 alone and in combination with chemotherapy in neuroblastoma. Oncotarget 6:10207-10221

111. Higgins B, Glenn K, Walz A, Tovar C, Filipovic Z, Hussain S, Lee E, Kolinsky K, Tannu S, Adames V et al (2014) Preclinical optimization of MDM2 antagonist scheduling for cancer treatment by using a model-based approach. Clin Cancer Res 20:3742-3752

112. Makii C, Oda K, Ikeda Y, Sone K, Hasegawa K, Uehara Y, Nishijima A, Asada K, Koso T, Fukuda T et al (2016) MDM2 is a potential therapeutic target and prognostic factor for ovarian clear cell carcinomas with wild type TP53. Oncotarget 7(46)

113. Esfandiari A, Hawthorne TA, Nakjang S, Lunec J (2016) Chemical inhibition of wild-type p53-induced phosphatase 1 (WIP1/PPM1D) by GSK2830371 potentiates the sensitivity to MDM2 inhibitors in a p53-dependent manner. Mol Cancer Ther 15:379-391

114. Wanzel M, Vischedyk JB, Gittler MP, Gremke N, Seiz JR, Hefter M, Noack M, Savai R, Mernberger M, Charles JP et al (2016) CRISPR-Cas9-based target validation for p53-reactivating model compounds. Nat Chem Biol 12:22-28

115. Goloudina AR, Mazur SJ, Appella E, Garrido C, Demidov ON (2012) Wip1 sensitizes p53-negative tumors to apoptosis by regulating the Bax/Bcl-xL ratio. Cell Cycle 11:1883-1887

116. Goloudina AR, Tanoue K, Hammann A, Fourmaux E, Le Guezennec X, Bulavin DV, Mazur SJ, Appella E, Garrido C, Demidov ON (2012) Wip1 promotes RUNX2-dependent apoptosis in p53-negative tumors and protects normal tissues during treatment with anticancer agents. Proc Natl Acad Sci U S A 109:E68-E75

117. Choi DW, Na W, Kabir MH, Yi E, Kwon S, Yeom J, Ahn JW, Choi HH, Lee Y, Seo KW et al (2013) WIP1, a homeostatic regulator of the DNA damage response, is targeted by HIPK2 for phosphorylation and degradation. Mol Cell 51:374-385

118. Clausse V, Goloudina AR, Uyanik B, Kochetkova EY, Richaud S, Fedorova OA, Hammann A, Bardou M, Barlev NA, Garrido C et al (2016) Wee1 inhibition potentiates Wip1-dependent p53-negative tumor cell death during chemotherapy. Cell Death Dis 7:e2195

119. Perez-Pinera P, Ousterout DG, Brunger JM, Farin AM, Glass KA, Guilak F, Crawford GE, Hartemink AJ, Gersbach CA (2013) Synergistic and tunable human gene activation by combinations of synthetic transcription factors. Nat Methods 10:239-242

120. Shen X-F, Zhao Y, Jiang J-P, Guan W-X, Du J-F (2017) Phosphatase Wip1 in immunity: an overview and update. Front Immunol 8:8

121. Uyanik B, Grigorash BB, Goloudina AR, Demidov ON (2017) DNA damage-induced phosphatase Wipl in regulation of hematopoiesis, immune system and inflammation. Cell Death Discov 3:17018

122. Schito ML, Demidov ON, Saito S, Ashwell JD, Appella E (2006) Wip1 phosphatase-deficient mice exhibit defective T cell maturation due to sustained p53 activation. J Immunol 176:4818-4825

123. Yi W, Hu X, Chen Z, Liu L, Tian Y, Chen H, Cong YS, Yang F, Zhang L, Rudolph KL et al (2015) Phosphatase Wip1 controls antigen-independent B-cell development in a p53-dependent manner. Blood 126:620-628

124. Chen Z, Yi W, Morita Y, Wang H, Cong Y, Liu J-P, Xiao Z, Rudolph KL, Cheng T, Ju Z (2015) Wip1 deficiency impairs haematopoietic stem cell function via $\mathrm{p} 53$ and mTORC1 pathways. Nat Commun 6:6808

125. Zhang Q, Zhang C, Chang F, Liang K, Yin X, Li X, Zhao K, Niu Q, Tian Z (2016) Wip 1 inhibits intestinal inflammation in inflammatory bowel disease. Cell Immunol 310:63-70 